\title{
Influence of Maternal Microbiome and Inflammatory Response in Preterm Birth: Recent Aspects of the Prevention of Preterm Birth
}

\author{
Hee Young Cho $\mathbb{D}$, Sung Shin Shim, Hee Jin Park $(\mathbb{D}$ and Dong Hyun Cha *(i) \\ Department of Obstetrics and Gynecology, CHA Gangnam Medical Center, CHA University, Seoul 06125, Korea; \\ hycho.md@cha.ac.kr (H.Y.C.); ogshinyss@chamc.co.kr (S.S.S.); coolsome72@chamc.co.kr (H.J.P.) \\ * Correspondence: chadh001@chamc.co.kr; Tel.: +82-2-3468-3023; Fax: +82-2-3468-3027
}

check for updates

Citation: Cho, H.Y.; Shim, S.S.; Park, H.J.; Cha, D.H. Influence of Maternal Microbiome and Inflammatory Response in Preterm Birth: Recent Aspects of the Prevention of Preterm Birth. Microbiol. Res. 2022, 13, 1-13. https://doi.org/10.3390/ microbiolres13010001

Academic Editors: Maria José Soares Mendes Giannini, Angel

Gonzalez Marin, Ana Marisa Fusco Almeida, Caroline Barcelos Costa-Orlandi and Marcia S.C. Melhem

Received: 11 November 2021 Accepted: 21 December 2021 Published: 22 December 2021

Publisher's Note: MDPI stays neutral with regard to jurisdictional claims in published maps and institutional affiliations.

Copyright: (C) 2021 by the authors. Licensee MDPI, Basel, Switzerland. This article is an open access article distributed under the terms and conditions of the Creative Commons Attribution (CC BY) license (https:// creativecommons.org/licenses/by/ $4.0 /)$.
Abstract: Preterm birth (PTB) is a global health issue and one of the most challenging problems affecting 12.9 million births worldwide. PTB is a multi-etiological disease and remains incompletely understood. The major cause of PTB is infection or inflammation and disruption of the vaginal microbiome, which affects the maternal immunologic response leading to PTB. The vaginal microbiome composition changes by a shift in the community are typically dominated by Lactobacillus during pregnancy. There are complex interactions between the maternal microbiome in pregnancy and the development of $\mathrm{PTB}$, therefore, researchers have struggled to connect the maternal microbiome with the dysregulation of the maternal immune response in cases of PTB. The host microbiome affects alterations of the microorganisms with external stimuli such as disease, nutrition, immunity, and behavior. In this review, we discuss the complex association between the maternal microbiome and the risk of PTB and also focus on recent aspects of the prevention of PTB.

Keywords: preterm birth; microbiome; microbiota; infection; inflammation; prevention

\section{Introduction}

Preterm birth (PTB) is defined as delivery less than 37 gestational weeks due to spontaneous onset of labor or preterm premature rupture of membranes (PPROM) [1]. PTB is a multifactorial disease and is the major cause of mortality and short- and long-term neonatal morbidity [2]. Many risk factors for PTB have been identified such as maternal age, low and very high maternal body mass index (BMI), drug use, conception via in vitro fertilization, a short cervix, previous history of PTB, and inflammation or infection of uterus, cervix, and placenta. Among them, inflammation or infection is considered to contribute up to $40 \%$ of PTB cases [3]. As well as maternal microbiomes, the measurement of cervical length (CL) by transvaginal ultrasound at 20-24 weeks of gestation is a useful method for the prediction of PTB for both singletons and twins [4]. Traditionally, PTB associated with infection was thought to come from an ascending infection or hematogenous transfer. During ascending infections, microbes such as Ureaplasma nucleatum, Ureaplasma parvum, and Candida spp. from the vagina go to the placenta, fetal membranes, and uterine cavity. In addition, using the standard clinical testing including amniotic fluid culture and PCR can identify microorganisms such as Ureaplasma urealyticum, Ureaplasma parvum, Bacteroides ureolyticus, Mycoplasma hominis, Gardnerella vaginalis, and Escherichia coli (E.coli) [5]. Recently, although rare, chorioamnionitis caused by Serratia marcescens has also been a risk factor reported [6].

In addition, asymptomatic bacteriuria during pregnancy is a possible risk factor for PTB. The prevalence of asymptomatic bacteriuria is $2-10 \%$ in pregnant women, and the prevalence is also the same in women who are not pregnant [7]. The common cause of bacteriuria includes E. coli and group B streptococcus (GBS), but the route of transmission has not yet been clearly established. Based on recent evidence that the bladder contains a 
very diverse microbiome, the role of the urinary tract in bacterial invasion of the amniotic cavity will need to be re-studied [8].

Maternal systemic infection and low genital tract infection due to Trichomonas vaginalis and Chlamydia trachomatis have been known, with increased risk of PTB [9]. The duration of pregnancy was prolonged among preterm labor patients without Mycoplasma hominis and Ureaplasma urealyticum, and screening for female genital tract Mycoplasmas during pre-pregnancy and early pregnancy may decrease the rate of PTB [10]. In addition, when pregnant women before 16 gestational weeks are diagnosed with bacterial vaginosis (BV), the risk of late miscarriage or PTB before 34 gestational weeks is increased seven times [11]. Hematogenous infection is when bacteria travel through blood from other parts of the body to cause the infection, and during pregnancy they travel to the maternal-fetal interface of the placenta [3]. The cause of PTB can occur by bacteria from the outside, but since numerous microorganisms are normally present in the human body, we cannot rule out what is caused by these bacteria [12,13].

Previous studies have uncovered the unique link between the microorganisms present in the human body and the diversity in various stages of life [2,13]. These studies revealed that microbiomes are individualized and vary depending on the individual's niche. In addition, they found the relationship between the host microbiome and external stimuli such as diabetes, inflammatory bowel disease, and PTB. The specific microbiome was investigated for the risk of PTB but other pregnancy-related microbiomes in placenta, uterus, and blood were not evaluated.

As seen above, the relationship between PTB and microbiomes has been continuously raised and research is being conducted. It seems that alteration in the vaginal microbiome interferes with the maternal immune system leading to PTB [14]. In this review, we discuss the association between the maternal microbiome and the risk of PTB and also focus on recent aspects of the prevention of PTB.

\section{Molecular-Based Approach of Microbial Communities}

During last decade, bacteriology was limited to microorganisms that were easily isolated and that could be cultured outside the human body. However, it is difficult to isolate microorganisms through culture only due to the complexity of microorganisms.

Recently, molecular-based techniques have been developed without using culture methods, and information on the various microorganisms in the human body have been obtained [13]. 'Microbiota' defines the total microorganisms in a defined community, and 'microbiome' refers to a combination of the words 'micro' and 'biome' meaning a 'characteristic microbial community' in a reasonably well-defined habitat. Microbiome defines a microbial community including properties, functions, and interaction with its environment. The definitions contain the general concepts of microbe-microbe and microbehost interactions. The microbiota constitute all living microorganisms including bacteria, archaea, fungi, algae, and small protists forming the microbiome. The human microbiome is now even considered to be last organ of humans. In addition, metagenomics refers to the collection of genomes and genes from the microbiota community and is obtained by shotgun sequencing for DNA. Metataxonomics is defined as the high-throughput process used to characterize the entire microbiota and create a metataxonomic tree, which shows the relationships between all sequences obtained. Microbial research starts with studying the microbial potential, and then studies the metabolic potential using available genetic materials. It is evolving toward the study of microbial functions using metabolic pathways (Table 1). 
Table 1. Development of methods for microbiome research [15].

\begin{tabular}{|c|c|c|}
\hline Microbial Function & Methods & Description \\
\hline Cells & Microscopy & $\begin{array}{l}\text { Detection of microbial phenotype and } \\
\text { colonization pattern }\end{array}$ \\
\hline \multirow{4}{*}{ DNA } & Cultoromics & $\begin{array}{c}\text { Species characterization and } \\
\text { cellular function }\end{array}$ \\
\hline & Metabarcoding & $\begin{array}{c}\text { Community composition and } \\
\text { microbial networks }\end{array}$ \\
\hline & Metagenomics & $\begin{array}{l}\text { The collection of genomes and genes from } \\
\text { microbiota community }\end{array}$ \\
\hline & Single cell genomics & Cell individuality \\
\hline RNA & Metatranscriptomics & Gene expression and active gene function \\
\hline Protein & Metaproteomics & Protein expression and metabolic function \\
\hline Metabolite & Metabolomics & $\begin{array}{l}\text { Metabolite production and } \\
\text { microbial production }\end{array}$ \\
\hline
\end{tabular}

\section{The Vaginal Microbiome in Normal Pregnancy}

The vaginal microbiome plays a very important role in women's health and disease development [16]. The vaginal microbiome changes during a woman's reproductive period from puberty to menopause, and it also varies a lot within the menstrual cycle [17]. The human vaginal microbiome is unique compared to the other human microbiomes, and lactobacilli are dominant for non-pregnant women of reproductive age [18]. Lactobacillus spp. produce hydrogen peroxide and lactic acid that defend for intrinsic and extrinsic pathogens [19]. During pregnancy, the vaginal microbiome goes through specific changes such as unbalanced colonization of Lactobacillus spp. and low bacterial diversity because of estradiol levels [20]. Ravel et al. [17] investigated characteristics of the bacterial component of the vaginal microbiome using the first application of next generation sequencing-based approaches. They collected the vaginal samples from asymptomatic women and described five distinct vaginal community state types (CST) using hierarchical clustering of relative abundance data. Four Lactobacillus spp. including Lactobacillus crispatus, L. gasseri, L. iners or L. jensenii dominate (CST-I, II, III, and V respectively). CST IV depletes lactobacilli and consists of anaerobic bacteria including Gardnerella, Atopobium, Prevotella, and Sneathia that are characterized by a highly diverse, polymicrobial community resembling bacterial vaginosis (BV). CST IV-A includes Peptoniphilus and Prevotella species, and CST IV-B is characterized by the enrichment of Atopobium and Gardnerella species.

Throughout the pregnancy period, IgG takes a key role in maintaining balance by neutralizing pathogens and controlling the innate immune system by complement activation [21]. The uterine immune environment undergoes a proinflammatory state, known as a Th1 dominant response, during the first and third trimester but changes the anti-inflammatory state, known as a Th2 dominant shift [2]. In addition, as glycogen increases after 20 weeks of gestation, the vaginal microbiome changes in the direction of increasing concentration of Lactobacillus [22]. Vaginal epithelial cells produce glycogen and it is transformed into lactic acid that induces a low vaginal $\mathrm{pH}(<4.5)$, which makes a favorable environment to inhibit the growth of microorganisms [23]. In uncomplicated normal pregnancies, the overall microbiomes remain less complex and less diverse, and more Lactobacillus are dominant than in the non-pregnant status, despite mild fluctuations in the subpopulation [24]. This stability is caused by more stable hormonal levels, the lack of period, and potential changes in sexual habits during pregnancy $[25,26]$. The diversity of the vaginal microbiome is higher during the first trimester than the second and third trimester of pregnancy due to elevated estrogen levels as the gestational age progresses [27]. Interestingly, as pregnancy approaches term, the microbiome becomes more similar to the non-pregnant state [28]. L. iners usually increases in older pregnant women and, in particular, it has been shown to be more prevalent towards the end of pregnancy [29]. As we describe, the role of vaginal microbiota is diverse during pregnancy (Table 2). 
Post-term pregnancies are associated with obstetrical complications compared to term pregnancies [30]. Judging from the report that PTB is related to the microbiome, it can be inferred that post-term pregnancies are also linked to the microbiome, but the exact relationship has not been studied yet; thus, this is an interesting field that needs further study in the future.

Table 2. Diversity of vaginal microbiota in pregnancy [31].

\begin{tabular}{ccc}
\hline Species & Microbiota & Effects of Microbiota \\
\hline Lactobacillus spp. & L. crispatus & Protective \\
& C. iners & Pontroversial \\
& L. jensenii & Protective \\
Bacterial Vaginosis & L. gasseri & Harmful \\
& Gardnerella & Harmful \\
& Bacteroides & Controversial/Harmful \\
Anaerobic Microbiota & Mobiluncus & Harmful \\
& Prevotella & Harmful \\
& Ureaplasma & Harmful \\
& Mycoplasma & Harmful \\
Aerobic Microbiota & Klebsiella & Controversial/Harmful \\
& Group Streptocuccus & Controversial
\end{tabular}

\section{Vaginal Microbiome and Preterm Birth}

During pregnancy, feto-maternal tolerance regulates the maternal immune response between anti-inflammatory and proinflammatory states. If this balance is disrupted by ascending microorganisms, the maternal immune system changes and leads to preterm labor [2]. It has been observed that the complexity and diversity of the vaginal microbiome increases with PTB, whereas the vaginal microbiome is less complex and less diverse in normal pregnancy. As mentioned before, the complement system plays an important role in normal pregnancy, therefore, complement activation leads to the chemotactic recruitment of immune cells including macrophage and dendritic cells involving PTB [32]. PTB is also related to proinflammatory cytokine profiles such as IL-1 $\beta$, IL-6, macrophage inflammatory protein (MIP)-1 $\beta$, and eotaxin [33]. Park et al. [34] investigated the roles of cytokines in the cervicovaginal fluid as predictive markers of PTB. MIP-1 $\alpha$, MIP- $1 \beta$, IL-6, IL-7, and IL-17 $\alpha$ in the cervicovaginal fluid were associated with PTB and IL-6, and IL-17 $\alpha$ had a higher sensitivity than the fetal fibronectin test.

Previous studies showed that Lactobacillus iners was associated with an increased risk of PTB despite the differences depending on ethnicity, whereas Lactobacillus crispatus showed a protective effect against PTB in all ethnicities [35,36]. In addition, the dominant population of Lactobacillus iners around 16 gestational weeks was closely related to the increased risk of shortening of the cervix and PTB before 34 gestational weeks [37]. As well as Lactobacillus spp., bacterial vaginosis-associated bacteria including Gardnerella vaginalis, Atopobium vaginae, and Veillonellaceae bacterium were associated with an increased risk of PTB before 34 gestational weeks [33]. Son et al. [38] investigated the comparisons of obstetrical outcomes according to the vaginal microbiota grouped by trimester. Abnormal vaginal microbiota, especially the presence of Klebsiella pneumonia, in the 2nd trimester was associated with a significant increase in PTB before 28 weeks.

Results of recent studies between the vaginal microbiome and PTB are presented in Table 3. Molecular-based new technologies have been applied to take advantage of the new information about the role of the vaginal microbiota in spontaneous labor and PTB. However, the current evidence is still limited, and clinical data have poor quality and results are controversial. Recently, most of the studies have demonstrated an association between the composition of the vaginal microbiota and PTB (Table 3). The more recently 
published studies provide evidence of an association between a dysbiotic microbiota and PTB, especially the role of $L$. iners in vaginal eubiosis and dysbiosis.

Table 3. Recent studies between Vaginal Microbiome and Preterm Birth.

\begin{tabular}{|c|c|c|}
\hline & Condition Studied & Summary \\
\hline 2019 Fettweis et al. [33] & $\begin{array}{c}45 \text { preterm and } 90 \text { term birth } \\
\text { controls }\end{array}$ & $\begin{array}{c}\text { Preterm-delivered women had } \\
\text { significantly lower vaginal levels of } \\
\text { Lactobacillus crispatus and higher } \\
\text { levels of Sneathia amnii, and Prevotella } \\
\text { species. }\end{array}$ \\
\hline 2018 Freitas et al. [24] & $\begin{array}{l}46 \text { preterm and } 170 \text { term } \\
\text { birth controls }\end{array}$ & $\begin{array}{c}\text { The preterm-delivered women had } \\
\text { increased richness and diversity and } \\
\text { higher Mycoplasma or Ureaplasma } \\
\text { prevalence. }\end{array}$ \\
\hline $\begin{array}{l}2017 \text { Callahan et al. } \\
\text { [39] }\end{array}$ & $\begin{array}{c}\text { Low risk for PTB: } \\
\text { predominantly Caucasian } \\
(n=39) \text { high-risk for PTB: } \\
\text { predominantly African } \\
\text { American }(n=96)\end{array}$ & $\begin{array}{c}\text { Lactobacillus crispatus was related to } \\
\text { low risk of PTB, while Lactobacillus } \\
\text { iners and Gardnerella vaginalis had } \\
\text { association with PTB. }\end{array}$ \\
\hline 2017 Stafford et al. [40] & $\begin{array}{c}\text { No preterm labor group } \\
(n=121), \text { preterm labor group } \\
(n=41)\end{array}$ & $\begin{array}{l}\text { The microbiome of women who } \\
\text { experienced PTB showed 2-fold lower } \\
\text { community state type (CST) } \\
\text { I-dominated microbiota at 20-22 } \\
\text { weeks. CST V was 2-fold higher in } \\
\text { the preterm-delivered women } \\
\text { compared to term-delivered women. }\end{array}$ \\
\hline 2017 Stout et al. [41] & $\begin{array}{l}\text { Nested case-control study, } \\
24 \text { cases and } 53 \text { controls }\end{array}$ & $\begin{array}{l}\text { The vaginal microbiome } \\
\text { demonstrated decreased vaginal } \\
\text { richness and Shannon diversity in } \\
\text { preterm delivery. }\end{array}$ \\
\hline 2016 Nelson et al. [42] & $\begin{array}{l}\text { Nulliparous African American } \\
\text { women, } 13 \text { preterm and } \\
27 \text { term birth controls }\end{array}$ & $\begin{array}{l}\text { Decreased bacterial diversity with } \\
\text { lower abundance of Coriobacteriaceae, } \\
\text { Sneathia, Prevotella, and Aerococcus } \\
\text { were found in preterm delivery. }\end{array}$ \\
\hline 2014 Romero et al. [43] & $\begin{array}{l}\text { Nested case-control study, } \\
18 \text { cases and } 72 \text { controls }\end{array}$ & $\begin{array}{l}\text { As pregnancy progressed, four } \\
\text { Lactobacillus spp. were increased and } \\
\text { anaerobic microbiomes were } \\
\text { decreased. }\end{array}$ \\
\hline
\end{tabular}

About one-third of PTB are preceded by preterm premature rupture of membranes (PPROM) [44]. The cause of PPROM seems to be ascending microorganisms, and the rupture of membranes also can become the entrance of ascending microbes, so infection can be both a cause and a result of PPROM. Ascending pathogens trigger inflammation pathways, leading to the development of chorioamnionitis and funisitis [45]. A few studies have investigated the relationship between vaginal microbiota and the risk of PPROM [46,47]. One study showed that vaginal microorganisms collected from normal pregnant women were characterized by Lactobacillus spp. dominance and low diversity, whereas about half of the pregnant women who subsequently experienced PPROM had intermediate or low Lactobacillus spp. dominance and high diversity [47]. In another prospective cohort study, the authors reported that reduced Lactobacillus spp. abundance and high diversity were shown in about $25 \%$ of pregnant women prior to PPROM, but only $3 \%$ of women delivered the baby at term without the rupture of membranes [48]. PPROM was associated with changes in the microbiome during pregnancy and a shift toward higher diversity, predominantly occurring during the second trimester, although a vaginal microbiota dominated with any bacterial species rather than Lactobacillus 
was related to subsequent PPROM throughout all of the pregnancy period including during the first trimester [46]. This study also found that the first trimester miscarriage associated with a Lactobacillus spp-depleted vaginal microbiome and women who had the risk of miscarriage in the first trimester had a 2-fold increased risk of PTB and 3-fold increased risk of PPROM [49]. This study showed the potential relationship between miscarriage and PPROM and the first trimester microbiome.

\section{Endometrial Microbiome in Preterm Birth}

The endometrium is the important site where the blastocyst is implanted during pregnancy and is a crucial place, not only for supporting fetal growth by supplying oxygen and nutrients but also for preventing infections to protect the embryo and fetus [50]. During the implantation period, the endometrium undergoes significant morphologic and functional change, which is followed by decidualization, and many immune cells compositions are altered. The endometrium is not a sterile tissue, and microorganisms at the endometrium interact with the endometrial epithelium and modify immune cell expression and cytokines. This change can affect endometrial receptivity and may impair adequate implantation [51].

As well as implantation, modification of the endometrial immune system during pregnancy has been related to adverse pregnancy outcomes including miscarriage, preeclampsia (PE), FGR, and PTB [52]. A previous study reported a relationship between reduced levels of Lactobacillus species in the endometrial microbiota and adverse pregnancy outcome [53]. Interestingly, the endometrial bacterial population was different from the bacterial composition of the vagina but was similar with that of the cervix regarding bacterial load and composition. To date, the role of endometrial microbiota in pregnancy outcomes is not fully understood and much remains to be investigated.

\section{Oral-Placental Microbiome in Preterm Birth}

The tolerogenic maternal immune response is the most important factor for a healthy pregnancy. Interruption of this state leads to maternal anti-fetal rejection, placental damage, and obstetric complications such as FGR and PTB. The cause of this allograft rejection is either a cellular ( $\mathrm{T}$ cell) or humoral (antibody) immune response, and severe rejection leads to fetal death akin to graft failure in organ transplantation. The fetal systemic inflammatory is similar to allograft rejection despite the absence of pathogens [54].

The possibility that the microbiome is present in the placental site was suggested [55]. The presence of fetal genital tract microbes colonization in the placenta or amniotic membranes has been thought to result in subclinical infection and a concomitant initiation of labor [56]. It is well known that ascending microbes from the vagina such as Ureaplasma, Mycoplasma, and GBS species have been related to placental colonization, chorioamnionitis, and PTB. Moreover, oral cavity microbes including Streptococcus and Fusobacterium spp. are known to contribute to the placental microbiome through hematogenous transfer [57]. Harboring bacteria were found in the placentas from term pregnant women who delivered by sterile cesarean section without infection sign and the amniotic fluid from women who had intact membranes [58]. A previous study reported that the placental microbiome from the vaginal and oral microbiomes was identified at the time of delivery using $16 \mathrm{~S}$ ribosomal RNA gene sequencing analysis. An increased Fusobacterium nucleatum, Gemella asaccharolytica, and Ureaplasma spp. was found in the fetal membranes, and this is associated with shorter gestation and PTB [59]. A placental microbiome that is similar to the oral cavity, the tonsils and tongue, including Firmicutes, Tenericutes, and Fusobacteria, was found in placentas that were previously undetectable in the microbiome using $16 \mathrm{~S}$ rRNA sequencing [56]. 
Even though common oral pathogens were identified in the placenta of women with periodontal disease, which is related to increased risk of PTB, it is not clear if the management of periodontal disease during pregnancy decreased PTB [60]. There is insufficient information to determine whether periodontal management can prevent preterm birth. Many studies have been performed to reveal the relationship between the existence of an oral-placental microbiome and adverse pregnancy outcomes, but this research area is still controversial.

\section{Gut Microbiome and Adverse Pregnancy Outcomes}

The gastrointestinal tract has the largest surface area in the body, and it is exposed to a diverse microbiome including bacteria, fungi, protozoa, viruses, and archaea. The most abundant bacteria in the human gastrointestinal tract is Bacteroidetes, occupying 70\%-90\% of the total gastrointestinal tract bacteria [61]. In addition to this, there are Firmicutes, Actinobacteria, and Proteobacteria, and about 1000 species of microorganism have diverse physiological roles to regulate immune homeostasis. Many studies have been performed about the gut microbiome in gastrointestinal diseases such as inflammatory bowel diseases, including ulcerative colitis and Crohn's disease.

During pregnancy, the maternal metabolic system shifts to increased gluconeogenesis, lipolysis, and insulin resistance for the growing fetus because maternal food intake and fat deposition increase as gestational age advances. Therefore, the maternal gut microbiome changes significantly during pregnancy. Previous studies investigated changes in the gut microbiome at the serial time points throughout pregnancy, and the composition of bacterial communities remained relatively stable during pregnancy. [61,62]. The gut microbiota in the first trimester of pregnancy is almost the same as the microbiota of healthy non-pregnant women. There are three different classes or enterotypes of gut microbiota in pregnancy: Enterotype I is dominated by Bacteroides; enterotype II is characterized by Prevotella; enterotype III is characterized by Ruminococcus. The three enterotypes are different depending on the diet and BMI of the individual and have different functions, metabolizing carbohydrates and proteins. Enterotype II clusters involved in lipid synthesis increase in vegetarian women, on the other hand, abundant enterotype I is associated with women who have rich animal protein and lipids [63]. For overweight and obese pregnant women, having abnormal insulin and adipokines levels, leads to alterations in bacterial abundance. There is an association between the microbiota and the level of metabolic hormones and cytokines during pregnancy. During normal placentation, uterine natural killer cells that are the most abundant immune cell type within the decidua have an important role for trophoblast invasiveness. However, obese pregnant women have reduced levels of decidual uterine natural killer cells and decreased proangiogenic factors [64]. Obesity is associated with increased proinflammatory cytokines including $\mathrm{T}$ cells, B cells, macrophages, neutrophil, and mast cells.

A previous study showed that the alterations in the gut microbiota during early pregnancy are related to an increased risk of hypertension and gestational diabetes mellitus (GDM) [65,66]. In particular, Ruminococcus and Blautia species are enriched in pregnant women with GDM. Another study showed that changes in the gut microbiota are associated with early-onset PE, and the composition of gut microbiota with earlyonset PE patients are significantly different from healthy pregnant women [67]. They also investigated that gut microbiota related to PE were associated with obesity, glucose metabolic disease, intestinal disorder, and proinflammatory states such as interleukin6 and lipopolysaccharide (LPS). Tersigni et al. [68] evaluated that increased bacterial translocation across the epithelium in early pregnancy is related to increased maternal levels of LPS, proinflammatory cytokines at the endometrial level, leading to increased risk of pregnancy loss. 
In order to maintain a stable pregnancy, it is important to maintain an anti-inflammatory state, but it is converted to an inflammatory state for parturition in the third trimester of pregnancy. Premature and unfavorable changes in the diversity and composition of the gut microbiota result in inflammatory status and lead to spontaneous preterm labor [69]. Moreover, it is possible for microbial seeding between the vagina and gut because there are anatomical links between the lower intestinal tract and the lower reproductive tract.

A recent study compared postpartum fecal samples of preterm birth women and term birth women, and they revealed decreased $\alpha$-diversity and reduction in operational taxonomic unit abundances of the Bifidobacterium and Streptococcus species [70]. Bifidobacterium inhibits LPS-induced NF- $\kappa$ B activation, IL-8, and COX-2 levels in vitro, thus, decreased Bifidobacterium could be the cause of inflammatory-induced preterm labor. As we have reviewed, the increased intestinal permeability of gut microbiota is associated with the increased risk of obstetric complications.

\section{Microbiomes. The Prevention of the PTB}

There is evidence to show the relationship between maternal microbiome profiles and increased risk of PTB, therefore, a large number of studies have investigated the effectiveness of antibiotics for the treatment and prevention of PTB. The maternal microbiome including the vaginal, oral-placenta, and gut microbiomes can play important roles in causing preterm birth (Figure 1).

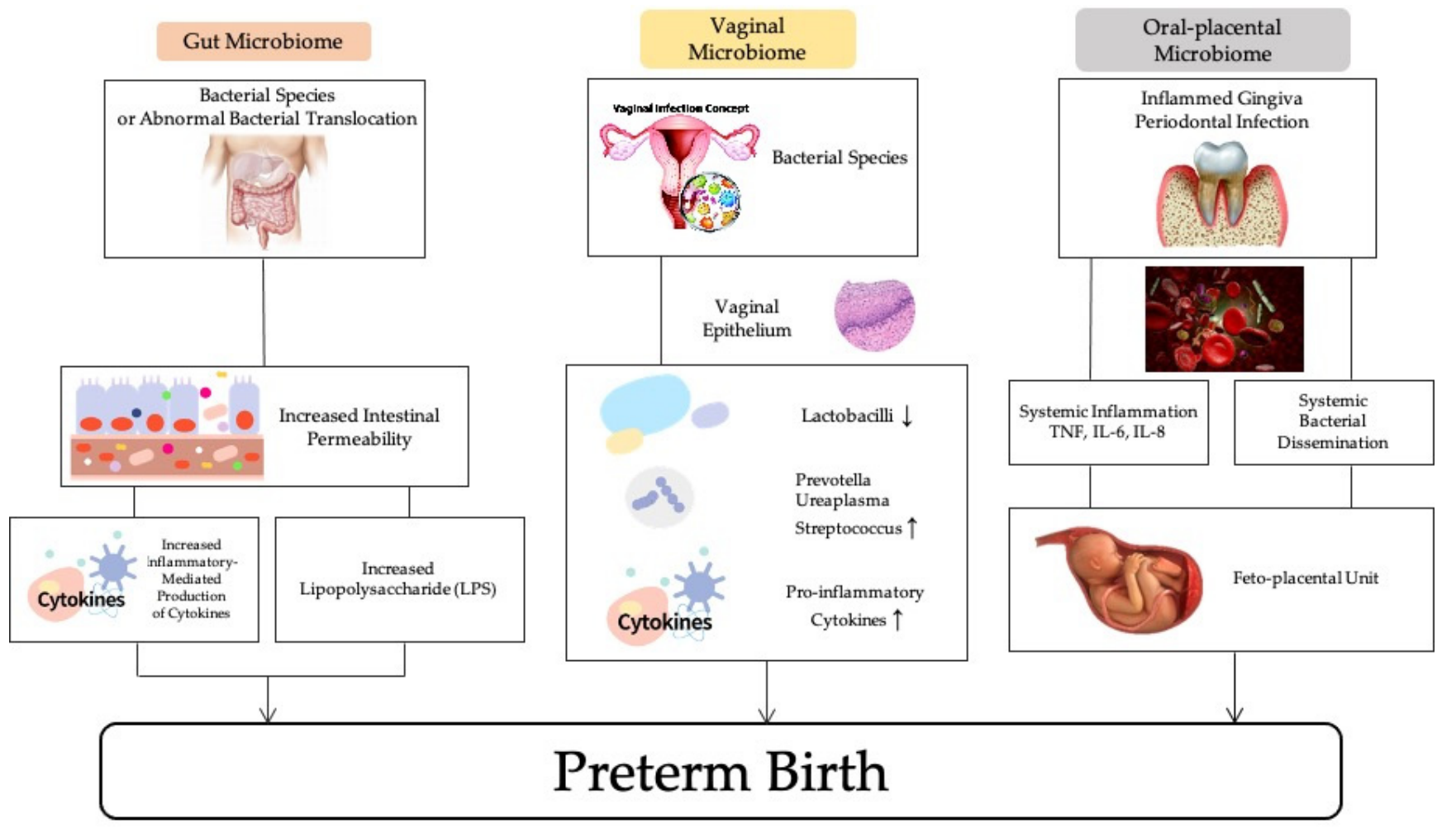

Figure 1. The association of maternal microbiomes and preterm birth.

The target of treatment for pregnant women was usually BV and the results were inconsistent [71,72]. The double blinded PREMEVA trial was conducted to evaluate the effect of oral clindamycin in early pregnancy to prevent late miscarriage (16-21 weeks of gestation) or spontaneous early PTB (22-32 weeks of gestation). There was no difference between the treatment and the placebo group [73]. However, another study showed that screening and treating BV in pregnant women with previous history of PTB is still effective in preventing PTB [71]. The use of certain antibiotics such as metronidazole may cause bacterial lysis and the release of endotoxins [74], and these are strong stimulators 
of inflammation and may enhance the inflammatory phenotype [75]. In addition, some antibiotics may be effective against Lactobacillus but not against microorganisms associated with BV, which was commonly found in antibiotic resistance genes [76].

Antibiotic treatment to ameliorate PTB could fail for women with abnormal vaginal microbes, positive fetal fibronectin, or previous PTB history, and it has raised interest in the positive regulation of vaginal microbiomes using probiotics or live bio-therapeutic products. Several studies have been conducted to reveal the effectiveness of probiotics to prevent PTB. Probiotics may be taken orally or, less commonly, vaginally. One study found that oral probiotic use in pregnancy did not decrease the risk of PTB [77], but an observational study revealed that probiotic milk intake in early pregnancy, not mid to late pregnancy, was related to reduce the risk of PTB [78]. Recent randomized controlled studies have reported that oral probiotics do not affect the vaginal microbiome during pregnancy $[79,80]$.

Increased concentration of folic acid has been found in the placenta of PTB women without excess gestational weight gain [81]. One study showed that folic acid consumption started after the first and second trimester is related to an increase in the risk of PTB [82], but another study found folic acid supplementation slightly reduces the risk of PTB [83].

\section{Conclusions}

The human microbiome plays an important role in female health and the pregnancy period. Dysbiosis of the vaginal, placental, or oral microbiomes are important triggers of infection and inflammation, and treatments could be used to modulate the composition of the microbiomes. Maternal microbiomes seem to be associated with the risk of PTB by modulating the maternal immune response. Among the maternal microbiomes, the vaginal microbiome has the strongest relationship with PTB. Other risk factors including genetic and anatomical factors cannot be modified but interventions for the maternal microbiomes could potentially decrease the risk of PTB. Understanding the complicated mechanisms and relationships between protective and harmful microorganisms could potentially help us to prevent and predict PTB.

Author Contributions: Conceptualization, all authors; writing-original draft preparation, H.Y.C.; writing-review and editing, all authors; supervision, D.H.C. All authors have read and agreed to the published version of the manuscript.

Funding: This research received no external funding.

Institutional Review Board Statement: Not applicable.

Informed Consent Statement: Not applicable.

Data Availability Statement: Not applicable.

Conflicts of Interest: The authors declare no conflict of interest.

\section{References}

1. Blencowe, H.; Cousens, S.; Chou, D.; Oestergaard, M.; Say, L.; Moller, A.B.; Kinney, M.; Lawn, J. Born too soon: The global epidemiology of 15 million preterm births. Reprod. Health 2013, 10 (Suppl. 1), S2. [CrossRef]

2. Integrative HMP Research network Consortium The Integrative Human Microbiome Project. Nature 2019, 569, 641-648. [CrossRef]

3. Goldenberg, R.L.; Culhane, J.F.; Iams, J.D.; Romero, R. Epidemiology and causes of preterm birth. Lancet 2008, 371, 75-84. [CrossRef]

4. da Fonseca, E.B.; Damião, R.; Moreira, D.A. Preterm birth prevention. Best Pract. Res. Clin. Obstet. Gynaecol. 2020, 69, 40-49. [CrossRef]

5. Cappelletti, M.; Della Bella, S.; Ferrazzi, E.; Mavilio, D.; Divanovic, S. Inflammation and preterm birth. J. Leukoc. Biol. 2016, 99, 67-78. [CrossRef] [PubMed]

6. $\quad$ Park, S.Y.; Kim, M.J.; Park, S.; Kim, N.I.; Oh, H.H.; Kim, J. Chorioamnionitis caused by Serratia marcescens in a healthcare worker: A case report. World J. Clin. Cases 2021, 9, 5689-5694. [CrossRef]

7. Stinson, L.F.; Payne, M.S. Infection-mediated preterm birth: Bacterial origins and avenues for intervention. Aust. N. Z. J. Obstet. Gynaecol. 2019, 59, 781-790. [CrossRef] 
8. Thomas-White, K.; Forster, S.C.; Kumar, N.; Van Kuiken, M.; Putonti, C.; Stares, M.D.; Hilt, E.E.; Price, T.K.; Wolfe, A.J.; Lawley, T.D. Culturing of female bladder bacteria reveals an interconnected urogenital microbiota. Nat. Commun. 2018, 9, 1557. [CrossRef]

9. Cotch, M.F.; Pastorek, J.G., 2nd; Nugent, R.P.; Hillier, S.L.; Gibbs, R.S.; Martin, D.H.; Eschenbach, D.A.; Edelman, R.; Carey, J.C.; Regan, J.A.; et al. Trichomonas vaginalis associated with low birth weight and preterm delivery. The Vaginal Infections and Prematurity Study Group. Sex. Transm. Dis. 1997, 24, 353-360. [CrossRef] [PubMed]

10. Jang, Y.S.; Min, J.W.; Kim, Y.S. Positive culture rate and antimicrobial susceptibilities of Mycoplasma hominis and Ureaplasma urealyticum. Obstet. Gynecol. Sci. 2019, 62, 127-133. [CrossRef]

11. Hay, P.E.; Lamont, R.F.; Taylor-Robinson, D.; Morgan, D.J.; Ison, C.; Pearson, J. Abnormal bacterial colonisation of the genital tract and subsequent preterm delivery and late miscarriage. BMJ 1994, 308, 295-298. [CrossRef]

12. Grice, E.A.; Segre, J.A. The human microbiome: Our second genome. Annu. Rev. Genom. Hum. Genet. 2012, 13, 151-170. [CrossRef] [PubMed]

13. Turnbaugh, P.J.; Ley, R.E.; Hamady, M.; Fraser-Liggett, C.M.; Knight, R.; Gordon, J.I. The human microbiome project. Nature 2007, 449, 804-810. [CrossRef] [PubMed]

14. Elovitz, M.A.; Gajer, P.; Riis, V.; Brown, A.G.; Humphrys, M.S.; Holm, J.B.; Ravel, J. Cervicovaginal microbiota and local immune response modulate the risk of spontaneous preterm delivery. Nat. Commun. 2019, 10, 1305. [CrossRef]

15. Berg, G.; Rybakova, D.; Fischer, D.; Cernava, T.; Vergès, M.C.; Charles, T.; Chen, X.; Cocolin, L.; Eversole, K.; Corral, G.H.; et al. Microbiome definition re-visited: Old concepts and new challenges. Microbiome 2020, 8, 103. [CrossRef]

16. MacIntyre, D.A.; Sykes, L.; Bennett, P.R. The human female urogenital microbiome: Complexity in normality. Emerg. Top Life Sci. 2017, 1, 363-372. [CrossRef] [PubMed]

17. Ravel, J.; Gajer, P.; Abdo, Z.; Schneider, G.M.; Koenig, S.S.; McCulle, S.L.; Karlebach, S.; Gorle, R.; Russell, J.; Tacket, C.O.; et al. Vaginal microbiome of reproductive-age women. Proc. Natl. Acad. Sci. USA 2011, 108 (Suppl. 1), 4680-4687. [CrossRef]

18. Belizário, J.E.; Napolitano, M. Human microbiomes and their roles in dysbiosis, common diseases, and novel therapeutic approaches. Front. Microbiol. 2015, 6, 1050. [CrossRef]

19. Parnell, L.A.; Briggs, C.M.; Mysorekar, I.U. Maternal microbiomes in preterm birth: Recent progress and analytical pipelines. Semin. Perinatol. 2017, 41, 392-400. [CrossRef]

20. DiGiulio, D.B.; Callahan, B.J.; McMurdie, P.J.; Costello, E.K.; Lyell, D.J.; Robaczewska, A.; Sun, C.L.; Goltsman, D.S.; Wong, R.J.; Shaw, G.; et al. Temporal and spatial variation of the human microbiota during pregnancy. Proc. Natl. Acad. Sci. USA 2015, 112, 11060-11065. [CrossRef]

21. van de Bovenkamp, F.S.; Hafkenscheid, L.; Rispens, T.; Rombouts, Y. The Emerging Importance of IgG Fab Glycosylation in Immunity. J. Immunol. 2016, 196, 1435-1441. [CrossRef]

22. Witkin, S.S. The vaginal microbiome, vaginal anti-microbial defence mechanisms and the clinical challenge of reducing infectionrelated preterm birth. BJOG Int. J. Obstet. Gynaecol. 2015, 122, 213-218. [CrossRef]

23. Petrova, M.I.; Lievens, E.; Malik, S.; Imholz, N.; Lebeer, S. Lactobacillus species as biomarkers and agents that can promote various aspects of vaginal health. Front. Physiol. 2015, 6, 81. [CrossRef]

24. Freitas, A.C.; Bocking, A.; Hill, J.E.; Money, D.M. Increased richness and diversity of the vaginal microbiota and spontaneous preterm birth. Microbiome 2018, 6, 117. [CrossRef] [PubMed]

25. Walther-António, M.R.; Jeraldo, P.; Berg Miller, M.E.; Yeoman, C.J.; Nelson, K.E.; Wilson, B.A.; White, B.A.; Chia, N.; Creedon, D.J. Pregnancy's stronghold on the vaginal microbiome. PLoS ONE 2014, 9, e98514. [CrossRef] [PubMed]

26. Gajer, P.; Brotman, R.M.; Bai, G.; Sakamoto, J.; Schütte, U.M.; Zhong, X.; Koenig, S.S.; Fu, L.; Ma, Z.S.; Zhou, X.; et al. Temporal dynamics of the human vaginal microbiota. Sci. Transl. Med. 2012, 4, 132ra152. [CrossRef] [PubMed]

27. Kroon, S.J.; Ravel, J.; Huston, W.M. Cervicovaginal microbiota, women's health, and reproductive outcomes. Fertil. Steril. 2018, 110, 327-336. [CrossRef]

28. Aagaard, K.; Riehle, K.; Ma, J.; Segata, N.; Mistretta, T.A.; Coarfa, C.; Raza, S.; Rosenbaum, S.; Van den Veyver, I.; Milosavljevic, A.; et al. A metagenomic approach to characterization of the vaginal microbiome signature in pregnancy. PLoS ONE 2012, 7, e36466. [CrossRef]

29. Goltsman, D.S.A.; Sun, C.L.; Proctor, D.M.; DiGiulio, D.B.; Robaczewska, A.; Thomas, B.C.; Shaw, G.M.; Stevenson, D.K.; Holmes, S.P.; Banfield, J.F.; et al. Metagenomic analysis with strain-level resolution reveals fine-scale variation in the human pregnancy microbiome. Genome Res. 2018, 28, 1467-1480. [CrossRef]

30. Olesen, A.W.; Westergaard, J.G.; Olsen, J. Perinatal and maternal complications related to postterm delivery: A national register-based study, 1978-1993. Am. J. Obstet. Gynecol. 2003, 189, 222-227. [CrossRef]

31. Tsonis, O.; Gkrozou, F.; Harrison, E.; Stefanidis, K.; Vrachnis, N.; Paschopoulos, M. Female genital tract microbiota affecting the risk of preterm birth: What do we know so far? A review. Eur. J. Obstet. Gynecol. Reprod. Biol. 2020, 245, 168-173. [CrossRef]

32. Dunn, A.B.; Dunlop, A.L.; Hogue, C.J.; Miller, A.; Corwin, E.J. The Microbiome and Complement Activation: A Mechanistic Model for Preterm Birth. Biol. Res. Nurs. 2017, 19, 295-307. [CrossRef] [PubMed]

33. Fettweis, J.M.; Serrano, M.G.; Brooks, J.P.; Edwards, D.J.; Girerd, P.H.; Parikh, H.I.; Huang, B.; Arodz, T.J.; Edupuganti, L.; Glascock, A.L.; et al. The vaginal microbiome and preterm birth. Nat. Med. 2019, 25, 1012-1021. [CrossRef] 
34. Park, S.; You, Y.A.; Yun, H.; Choi, S.J.; Hwang, H.S.; Choi, S.K.; Lee, S.M.; Kim, Y.J. Cervicovaginal fluid cytokines as predictive markers of preterm birth in symptomatic women. Obstet. Gynecol. Sci. 2020, 63, 455-463. [CrossRef]

35. Petricevic, L.; Domig, K.J.; Nierscher, F.J.; Sandhofer, M.J.; Fidesser, M.; Krondorfer, I.; Husslein, P.; Kneifel, W.; Kiss, H. Characterisation of the vaginal Lactobacillus microbiota associated with preterm delivery. Sci. Rep. 2014, 4, 5136. [CrossRef]

36. Tabatabaei, N.; Eren, A.M.; Barreiro, L.B.; Yotova, V.; Dumaine, A.; Allard, C.; Fraser, W.D. Vaginal microbiome in early pregnancy and subsequent risk of spontaneous preterm birth: A case-control study. BJOG Int. J. Obstet. Gynaecol. 2019, 126, 349-358. [CrossRef]

37. Gerson, K.D.; McCarthy, C.; Elovitz, M.A.; Ravel, J.; Sammel, M.D.; Burris, H.H. Cervicovaginal microbial communities deficient in Lactobacillus species are associated with second trimester short cervix. Am. J. Obstet. Gynecol. 2020, 222, 491.e1. [CrossRef]

38. Son, K.A.; Kim, M.; Kim, Y.M.; Kim, S.H.; Choi, S.J.; Oh, S.Y.; Roh, C.R.; Kim, J.H. Prevalence of vaginal microorganisms among pregnant women according to trimester and association with preterm birth. Obstet. Gynecol. Sci. 2018, 61, 38-47. [CrossRef] [PubMed]

39. Callahan, B.J.; DiGiulio, D.B.; Goltsman, D.S.A.; Sun, C.L.; Costello, E.K.; Jeganathan, P.; Biggio, J.R.; Wong, R.J.; Druzin, M.L.; Shaw, G.M.; et al. Replication and refinement of a vaginal microbial signature of preterm birth in two racially distinct cohorts of US women. Proc. Natl. Acad. Sci. USA 2017, 114, 9966-9971. [CrossRef] [PubMed]

40. Stafford, G.P.; Parker, J.L.; Amabebe, E.; Kistler, J.; Reynolds, S.; Stern, V.; Paley, M.; Anumba, D.O.C. Spontaneous Preterm Birth Is Associated with Differential Expression of Vaginal Metabolites by Lactobacilli-Dominated Microflora. Front. Physiol. 2017, 8, 615. [CrossRef]

41. Stout, M.J.; Zhou, Y.; Wylie, K.M.; Tarr, P.I.; Macones, G.A.; Tuuli, M.G. Early pregnancy vaginal microbiome trends and preterm birth. Am. J. Obstet. Gynecol. 2017, 217, 356.e1. [CrossRef]

42. Nelson, D.B.; Shin, H.; Wu, J.; Dominguez-Bello, M.G. The Gestational Vaginal Microbiome and Spontaneous Preterm Birth among Nulliparous African American Women. Am. J. Perinatol. 2016, 33, 887-893. [CrossRef] [PubMed]

43. Romero, R.; Hassan, S.S.; Gajer, P.; Tarca, A.L.; Fadrosh, D.W.; Bieda, J.; Chaemsaithong, P.; Miranda, J.; Chaiworapongsa, T.; Ravel, J. The vaginal microbiota of pregnant women who subsequently have spontaneous preterm labor and delivery and those with a normal delivery at term. Microbiome 2014, 2, 18. [CrossRef] [PubMed]

44. Parry, S.; Strauss, J.F. 3rd. Premature rupture of the fetal membranes. N. Engl. J. Med. 1998, 338, 663-670. [CrossRef]

45. Puri, K.; Taft, D.H.; Ambalavanan, N.; Schibler, K.R.; Morrow, A.L.; Kallapur, S.G. Association of Chorioamnionitis with Aberrant Neonatal Gut Colonization and Adverse Clinical Outcomes. PLoS ONE 2016, 11, e0162734. [CrossRef]

46. Brown, R.G.; Chan, D.; Terzidou, V.; Lee, Y.S.; Smith, A.; Marchesi, J.R.; MacIntyre, D.A.; Bennett, P.R. Prospective observational study of vaginal microbiota pre- and post-rescue cervical cerclage. BJOG Int. J. Obstet. Gynaecol. 2019, 126, 916-925. [CrossRef] [PubMed]

47. Brown, R.G.; Marchesi, J.R.; Lee, Y.S.; Smith, A.; Lehne, B.; Kindinger, L.M.; Terzidou, V.; Holmes, E.; Nicholson, J.K.; Bennett, P.R.; et al. Vaginal dysbiosis increases risk of preterm fetal membrane rupture, neonatal sepsis and is exacerbated by erythromycin. BMC Med. 2018, 16, 9. [CrossRef] [PubMed]

48. Brown, R.G.; Al-Memar, M.; Marchesi, J.R.; Lee, Y.S.; Smith, A.; Chan, D.; Lewis, H.; Kindinger, L.; Terzidou, V.; Bourne, T.; et al. Establishment of vaginal microbiota composition in early pregnancy and its association with subsequent preterm prelabor rupture of the fetal membranes. Transl. Res. 2019, 207, 30-43. [CrossRef] [PubMed]

49. Al-Memar, M.; Bobdiwala, S.; Fourie, H.; Mannino, R.; Lee, Y.S.; Smith, A.; Marchesi, J.R.; Timmerman, D.; Bourne, T.; Bennett, P.R.; et al. The association between vaginal bacterial composition and miscarriage: A nested case-control study. BJOG Int. J. Obstet. Gynaecol. 2020, 127, 264-274. [CrossRef]

50. Kitaya, K.; Yasuo, T.; Tada, Y.; Hayashi, T.; Iwaki, Y.; Karita, M.; Funabiki, M.; Taguchi, S.; Spillers, D.; Nakamura, Y.; et al. Unusual inflammation in gynecologic pathology associated with defective endometrial receptivity. Histol. Histopathol. 2014, 29, 1113-1127. [CrossRef]

51. Di Simone, N.; Santamaria Ortiz, A.; Specchia, M.; Tersigni, C.; Villa, P.; Gasbarrini, A.; Scambia, G.; D’Ippolito, S. Recent Insights on the Maternal Microbiota: Impact on Pregnancy Outcomes. Front. Immunol. 2020, 11, 528202. [CrossRef]

52. Liu, S.; Diao, L.; Huang, C.; Li, Y.; Zeng, Y.; Kwak-Kim, J.Y.H. The role of decidual immune cells on human pregnancy. J. Reprod. Immunol. 2017, 124, 44-53. [CrossRef]

53. Moreno, I.; Franasiak, J.M. Endometrial microbiota-new player in town. Fertil. Steril. 2017, 108, 32-39. [CrossRef]

54. Kim, C.J.; Romero, R.; Chaemsaithong, P.; Kim, J.S. Chronic inflammation of the placenta: Definition, classification, pathogenesis, and clinical significance. Am. J. Obstet. Gynecol. 2015, 213, S53-S69. [CrossRef]

55. Mor, G.; Kwon, J.Y. Trophoblast-microbiome interaction: A new paradigm on immune regulation. Am. J. Obstet. Gynecol. 2015, 213, S131-S137. [CrossRef] [PubMed]

56. Aagaard, K.; Ma, J.; Antony, K.M.; Ganu, R.; Petrosino, J.; Versalovic, J. The placenta harbors a unique microbiome. Sci. Transl. Med. 2014, 6, 237ra65. [CrossRef]

57. Vander Haar, E.L.; So, J.; Gyamfi-Bannerman, C.; Han, Y.W. Fusobacterium nucleatum and adverse pregnancy outcomes: Epidemiological and mechanistic evidence. Anaerobe 2018, 50, 55-59. [CrossRef] [PubMed]

58. Parris, K.M.; Amabebe, E.; Cohen, M.C.; Anumba, D.O. Placental microbial-metabolite profiles and inflammatory mechanisms associated with preterm birth. J. Clin. Pathol. 2021, 74, 10-18. [CrossRef] [PubMed] 
59. Doyle, R.M.; Harris, K.; Kamiza, S.; Harjunmaa, U.; Ashorn, U.; Nkhoma, M.; Dewey, K.G.; Maleta, K.; Ashorn, P.; Klein, N. Bacterial communities found in placental tissues are associated with severe chorioamnionitis and adverse birth outcomes. PLoS ONE 2017, 12, e0180167. [CrossRef]

60. Puertas, A.; Magan-Fernandez, A.; Blanc, V.; Revelles, L.; O’Valle, F.; Pozo, E.; León, R.; Mesa, F. Association of periodontitis with preterm birth and low birth weight: A comprehensive review. J. Matern. Fetal. Neonatal. Med. 2018, 31, 597-602. [CrossRef]

61. Donaldson, G.P.; Lee, S.M.; Mazmanian, S.K. Gut biogeography of the bacterial microbiota. Nat. Rev. Microbiol. 2016, 14, 20-32. [CrossRef] [PubMed]

62. Dunlop, A.L.; Knight, A.K.; Satten, G.A.; Cutler, A.J.; Wright, M.L.; Mitchell, R.M.; Read, T.D.; Mulle, J.; Hertzberg, V.S.; Hill, C.C.; et al. Stability of the vaginal, oral, and gut microbiota across pregnancy among African American women: The effect of socioeconomic status and antibiotic exposure. PeerJ 2019, 7, e8004. [CrossRef] [PubMed]

63. Barrett, H.L.; Gomez-Arango, L.F.; Wilkinson, S.A.; McIntyre, H.D.; Callaway, L.K.; Morrison, M.; Dekker Nitert, M. A Vegetarian Diet Is a Major Determinant of Gut Microbiota Composition in Early Pregnancy. Nutrients 2018, 10, 890. [CrossRef]

64. Perdu, S.; Castellana, B.; Kim, Y.; Chan, K.; DeLuca, L.; Beristain, A.G. Maternal obesity drives functional alterations in uterine NK cells. JCI Insight 2016, 1, e85560. [CrossRef] [PubMed]

65. Zheng, W.; Xu, Q.; Huang, W.; Yan, Q.; Chen, Y.; Zhang, L.; Tian, Z.; Liu, T.; Yuan, X.; Liu, C.; et al. Gestational Diabetes Mellitus Is Associated with Reduced Dynamics of Gut Microbiota during the First Half of Pregnancy. Msystems 2020, 5, e00109-20. [CrossRef] [PubMed]

66. Ma, S.; You, Y.; Huang, L.; Long, S.; Zhang, J.; Guo, C.; Zhang, N.; Wu, X.; Xiao, Y.; Tan, H. Alterations in Gut Microbiota of Gestational Diabetes Patients During the First Trimester of Pregnancy. Front. Cell. Infect. Microbiol. 2020, 10, 58. [CrossRef]

67. Lv, L.J.; Li, S.H.; Li, S.C.; Zhong, Z.C.; Duan, H.L.; Tian, C.; Li, H.; He, W.; Chen, M.C.; He, T.W.; et al. Early-Onset Preeclampsia Is Associated With Gut Microbial Alterations in Antepartum and Postpartum Women. Front. Cell. Infect. Microbiol. 2019, 9, 224. [CrossRef]

68. Tersigni, C.; D’Ippolito, S.; Di Nicuolo, F.; Marana, R.; Valenza, V.; Masciullo, V.; Scaldaferri, F.; Malatacca, F.; de Waure, C.; Gasbarrini, A.; et al. Recurrent pregnancy loss is associated to leaky gut: A novel pathogenic model of endometrium inflammation? J. Transl. Med. 2018, 16, 102. [CrossRef]

69. Aghaeepour, N.; Ganio, E.A.; McIlwain, D.; Tsai, A.S.; Tingle, M.; Van Gassen, S.; Gaudilliere, D.K.; Baca, Q.; McNeil, L.; Okada, R.; et al. An immune clock of human pregnancy. Sci. Immunol. 2017, 2, 1-11. [CrossRef]

70. Dahl, C.; Stanislawski, M.; Iszatt, N.; Mandal, S.; Lozupone, C.; Clemente, J.C.; Knight, R.; Stigum, H.; Eggesbø, M. Gut microbiome of mothers delivering prematurely shows reduced diversity and lower relative abundance of Bifidobacterium and Streptococcus. PLoS ONE 2017, 12, e0184336. [CrossRef] [PubMed]

71. Brocklehurst, P.; Gordon, A.; Heatley, E.; Milan, S.J. Antibiotics for treating bacterial vaginosis in pregnancy. Cochrane Database Syst. Rev. 2013, 1, CD000262. [CrossRef]

72. Lamont, R.F.; Nhan-Chang, C.L.; Sobel, J.D.; Workowski, K.; Conde-Agudelo, A.; Romero, R. Treatment of abnormal vaginal flora in early pregnancy with clindamycin for the prevention of spontaneous preterm birth: A systematic review and metaanalysis. Am. J. Obstet. Gynecol. 2011, 205, 177-190. [CrossRef]

73. Subtil, D.; Brabant, G.; Tilloy, E.; Devos, P.; Canis, F.; Fruchart, A.; Bissinger, M.C.; Dugimont, J.C.; Nolf, C.; Hacot, C.; et al. Early clindamycin for bacterial vaginosis in pregnancy (PREMEVA): A multicentre, double-blind, randomised controlled trial. Lancet 2018, 392, 2171-2179. [CrossRef]

74. Morency, A.M.; Bujold, E. The effect of second-trimester antibiotic therapy on the rate of preterm birth. J. Obstet. Gynaecol. Can. 2007, 29, 35-44. [CrossRef]

75. Migale, R.; Herbert, B.R.; Lee, Y.S.; Sykes, L.; Waddington, S.N.; Peebles, D.; Hagberg, H.; Johnson, M.R.; Bennett, P.R.; MacIntyre, D.A. Specific Lipopolysaccharide Serotypes Induce Differential Maternal and Neonatal Inflammatory Responses in a Murine Model of Preterm Labor. Am. J. Pathol. 2015, 185, 2390-2401. [CrossRef]

76. Bostwick, D.G.; Woody, J.; Hunt, C.; Budd, W. Antimicrobial resistance genes and modelling of treatment failure in bacterial vaginosis: Clinical study of 289 symptomatic women. J. Med. Microbiol. 2016, 65, 377-386. [CrossRef] [PubMed]

77. Grev, J.; Berg, M.; Soll, R. Maternal probiotic supplementation for prevention of morbidity and mortality in preterm infants. Cochrane Database Syst. Rev. 2018, 12, Cd012519. [CrossRef]

78. Nordqvist, M.; Jacobsson, B.; Brantsæter, A.L.; Myhre, R.; Nilsson, S.; Sengpiel, V. Timing of probiotic milk consumption during pregnancy and effects on the incidence of preeclampsia and preterm delivery: A prospective observational cohort study in Norway. BMJ Open 2018, 8, e018021. [CrossRef] [PubMed]

79. Yang, S.; Reid, G.; Challis, J.R.G.; Gloor, G.B.; Asztalos, E.; Money, D.; Seney, S.; Bocking, A.D. Effect of Oral Probiotic Lactobacillus rhamnosus GR-1 and Lactobacillus reuteri RC-14 on the Vaginal Microbiota, Cytokines and Chemokines in Pregnant Women. Nutrients 2020, 12, 368. [CrossRef] [PubMed]

80. Husain, S.; Allotey, J.; Drymoussi, Z.; Wilks, M.; Fernandez-Felix, B.M.; Whiley, A.; Dodds, J.; Thangaratinam, S.; McCourt, C.; Prosdocimi, E.M.; et al. Effects of oral probiotic supplements on vaginal microbiota during pregnancy: A randomised, double-blind, placebo-controlled trial with microbiome analysis. BJOG Int. J. Obstet. Gynaecol. 2020, 127, 275-284. [CrossRef]

81. Antony, K.M.; Ma, J.; Mitchell, K.B.; Racusin, D.A.; Versalovic, J.; Aagaard, K. The preterm placental microbiome varies in association with excess maternal gestational weight gain. Am. J. Obstet. Gynecol. 2015, 212. [CrossRef] [PubMed] 
82. Alwan, N.A.; Greenwood, D.C.; Simpson, N.A.; McArdle, H.J.; Cade, J.E. The relationship between dietary supplement use in late pregnancy and birth outcomes: A cohort study in British women. BJOG Int. J. Obstet. Gynaecol. 2010, 117, 821-829. [CrossRef] [PubMed]

83. Mantovani, E.; Filippini, F.; Bortolus, R.; Franchi, M. Folic acid supplementation and preterm birth: Results from observational studies. BioMed Res. Int. 2014, 2014, 481914. [CrossRef] [PubMed] 